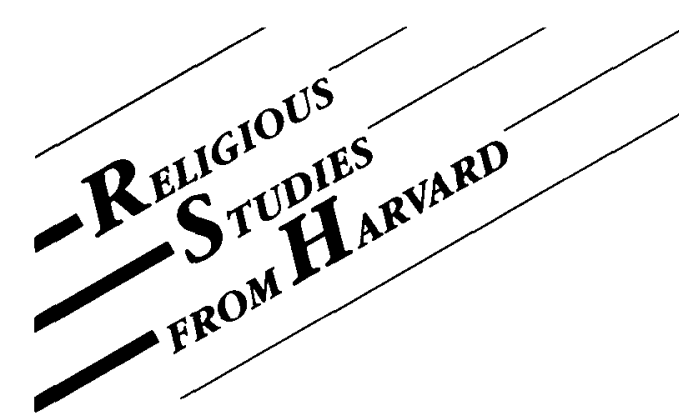

\title{
THE FUTURE OF EARLY
} CHRISTIANITY

Essays in Honor of Helmut Koester

Edited by BIRGER A. PEARSON

Thirty-nine scholars tackle open questions in six areas of Koester's most intense work and impact. Koester himself supplies an Epilogue on "Current Issues in New Testament Scholarship." $\$ 39.95$ cloth

\section{SPIRITUAL GUIDES OF} THE THIRD CENTURY

A Semiotic Study of the Guide-

Disciple Relationship in

Christianity, Neoplatonism, Hermetism, and Gnosticism

RICHARD J. VALANTASIS

Valantasis demonstrates the importance of the guide-disciple relationship in several competing Hellenistic religious movements.

$\$ 16.95$ paper

\section{A JEW IN THE COURT OF THE FOREIGN KING Ancient Jewish Court Legends LAWRENCE M. WILLS}

This first such comprehensive study integrates historical-critical methods, folklore studies, and literary criticism. $\$ 14.95$ paper

\section{THE CHRISTIAN LIFE}

\section{Traditional Metaphors and} Contemporary Theologies

HARRIET CRABTREE

Harriet Crabtree explores "servanthood," "stewardship" and eight other traditional metaphors and their potential for contemporary renewal of faith. $\$ 13.95$ paper

\section{REVELATION}

Vision of a Just World

ELISABETH SCHÜSSLER FIORENZA

Charts a new and provocative course of interpretation, opening to the reader the world vision of this powerful book. $\$ 9.95$ paper

\section{THE LEGACY OF H. RICHARD NIEBUHR} Edited by RONALD F. THIEMANN Noted theologians assess one of America's most distinguished, but often overlooked, theologian's contributions. $\$ 13.95$ paper

\section{THE HISTORY OF POLISH REFORMATION}

STANISLAW LUBIENIECKI

Edited by GEORGE HUNTSTON WILLIAMS

Core documents along with 250 illustrations and commentaries provide an authoritative resource for interpretation. $\$ 110.00$ cloth July

\section{THE EMPEROR AND THE GODS}

\section{Images from the Time of Trajan}

DANIEL N. SCHOWALTER

Schowalter demonstrates the complexity of the emperor cult in relation to ritual, to the structure of political power, and to the fledgling Christian movement.

$\$ 14.95$ paper April

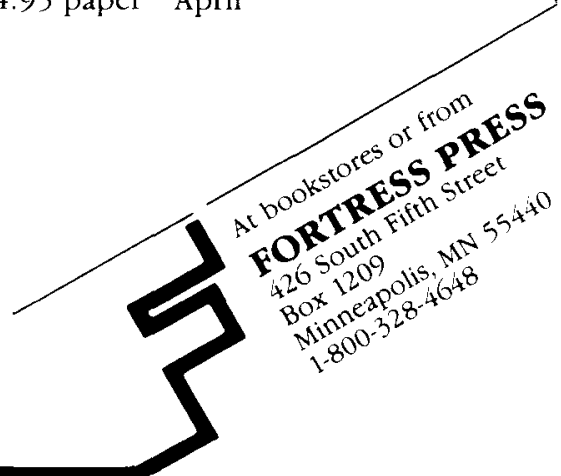




\section{4:3 JULY 1991}

229 The Heretical Woman as Symbol in Alexander, Athanasius, Epiphanius, and Jerome Virginia Burrus

249 Maimonides' Doctrine of Creation Norbert M. Samuelson

273 The Christian Science Textbook: An Analysis of the Religious Authority of Science and Health by Mary Baker Eddy David L. Weddle

299 From Arbor Day to the Environmental Sabbath: Nature, Liturgy, and American Protestantism Leigh Eric Schmidt

325 On the Uses of Heresy: Leonard Feeney, Mary Douglas, and the Notre Dame Football Team Mark Massa

Notes and Observations

343 Choliambs for Mary in a Papyrus Phylactery David R. Jordan

347 Books Received 